\title{
Area use and movement patterns of wild and escaped farmed Atlantic salmon before and during spawning in a large Norwegian river
}

\author{
Karina Moe ${ }^{1,2}$, Tor F. Næsje ${ }^{1, *}$, Thrond O. Haugen ${ }^{2}$, Eva M. Ulvan' ${ }^{1}$, Tonje Aronsen ${ }^{1}$, \\ Tomas Sandnes $^{3}$, Eva B. Thorstad ${ }^{1}$ \\ ${ }^{1}$ Norwegian Institute for Nature Research (NINA), PO Box 5685 Sluppen, 7485 Trondheim, Norway \\ ${ }^{2}$ Norwegian University of Life Sciences (NMBU), PO Box 5003 NMBU, 1432 Ås, Norway \\ ${ }^{3}$ Aqua Kompetanse AS, 7770 Flatanger, Norway
}

\begin{abstract}
We compared the within-river movements and distribution of wild and escaped farmed Atlantic salmon Salmo salar before and during spawning in the Namsen river system of Central Norway. A total of 74 wild and 43 escaped farmed salmon were captured at sea, tagged with radio transmitters and released. Based on our examinations, most, if not all salmon (farmed and wild) entering the River Namsen were sexually mature. Farmed salmon entering the river system had a higher probability than wild individuals of reaching the migration barrier in the upper part of the river, $70 \mathrm{~km}$ from the sea. During the pre-spawning and spawning periods, farmed salmon were located mainly in the upper parts (50 to $70 \mathrm{~km}$ from the sea), whereas wild salmon were evenly distributed along the entire river during both periods. Consequently, the probability of farmed $\times$ wild inter-breeding varied among river sections. Our finding that the distribution of escaped farmed salmon may differ from that of wild salmon and among river sections in the prespawning and spawning periods - and that it may also vary over time-must be taken into consideration when (1) designing monitoring programs aimed at estimating the proportion of escaped farmed salmon in rivers and (2) when interpreting monitoring results. Furthermore, targeted fishing in the river aimed at reducing the number of farmed salmon prior to spawning may be more effective in upper rivers sections, and below major migration barriers.
\end{abstract}

KEY WORDS: Radio telemetry · Farmed escapees · Within-river movements · Pre spawning · Spawning period $\cdot$ Introgression risk $\cdot$ River Namsen

\section{INTRODUCTION}

The population of wild Atlantic salmon Salmo salar L. has declined over the last decades, despite efforts to reduce fishing pressure (ICES 2014). In areas of intensive salmon aquaculture, populations of wild salmonids may be negatively impacted by increases in the abundance of salmon lice Lepeophtheirus salmonis and other infections. In addition, farmed salmon that escape from net pens can migrate to the rivers where they may interbreed with native salmon

${ }^{*}$ Corresponding author: tor.naesje@nina.no
(Jensen et al. 2010, Taranger et al. 2015, Thorstad et al. 2015). Norway is the world's largest producer of farmed Atlantic salmon, with a total production of 1220000 metric tons in 2014. In comparison, the total catches of wild Atlantic salmon in Norway were $490 \mathrm{t}$ in the same year (Anonymous 2015b).

Escaped farmed salmon can contribute to the depletion of wild salmon populations because of their reduced adaptations to environmental conditions. Wild salmon populations differ in genetic composition as a result of local adaptations to different eco-

(C) The authors 2016. Open Access under Creative Commons by Attribution Licence. Use, distribution and reproduction are unrestricted. Authors and original publication must be credited. 
logical conditions (Garcia de Leaniz et al. 2007). The farmed Atlantic salmon in Norway were founded by individuals from a few wild strains in the early 1970s, and have less genetic variation than the wild population due to domestication and selective breeding (Skaala et al. 2005, Karlsson et al. 2010). Consequently, crossbreeding between wild and farmed fish may lead to lower genetic variation and loss of local adaptability in wild Atlantic salmon populations (Ferguson et al. 2007, Glover et al. 2012, 2013). Moreover, the offspring of farmed Atlantic salmon, hybrids and backcrosses have lower survival as juveniles than wild offspring (Fleming et al. 2000, McGinnity et al. 2003). Escaped farmed individuals migrating into rivers may therefore have negative ecological and genetic effects on wild Atlantic salmon populations (Fleming et al. 2000, McGinnity et al. 2003). The average proportion of escaped farmed salmon in samples from Norwegian rivers close to the spawning period varied between 11 and 18\% between 1999 and 2014 (Anonymous 2015b), and genetic hybridization between farmed and wild salmon has been documented (Glover et al. 2012, 2013).

Wild Atlantic salmon return to their natal river to spawn (Hansen et al. 1989, Harden Jones 1968). Imprinting of the environmental characteristics of the river during the smolt and post-smolt migration seems pivotal for precise homing (Hansen et al. 1989). Due to a lack of river imprinting and river experience, farmed salmon may migrate to the uppermost river stretches that are accessible for anadromous salmonids, or to other major migration barriers (Butler et al. 2005, Heggberget et al. 1996, Thorstad et al. 1998). In addition, they may perform more and longer up- and downstream movements than wild Atlantic salmon during the spawning period (Heggberget et al. 1996, Thorstad et al. 1998). The within-river migration of wild Atlantic salmon has been well studied, whereas there are few studies comparing the migration patterns of wild and escaped farmed Atlantic salmon before and during the spawning period (Thorstad et al. 2008). Withinriver movements and distribution before and during spawning may be important for evaluating the risk of genetic hybridization between farmed and wild salmon, for developing methods for monitoring the incidence of escaped farmed fish, and for developing measures to remove escaped farmed individuals from rivers.

In 1993, Thorstad et al. (1998) studied the behavior and area use of escaped farmed and wild Atlantic salmon during the spawning period in the River Namsen. They found that farmed salmon were dis- tributed higher upstream in the river than wild salmon, and that farmed salmon exhibited more and longer up- and downstream movements, although the study was based on a small sample size of escaped farmed salmon. In the present study, one of our aims was to confirm in a more comprehensive study that these findings are still valid after 19 additional years of intentional and unintentional selection of farmed salmon. Moreover, we aimed to collect more extensive information on salmon behavior during the pre-spawning period.

The main goals of this study were to compare the area use and movement patterns of wild and escaped farmed Atlantic salmon before and during spawning in a large Norwegian river. Specifically, we used radio telemetry to investigate the following questions: (1) Are wild and farmed Atlantic salmon located in the same river stretches during the prespawning and spawning period, and (2) do wild and farmed Atlantic salmon exhibit the same movement patterns prior to and during the spawning period?

\section{MATERIALS AND METHODS}

\section{Study area}

The Namsen river system in Central Norway has a catchment area of $6265 \mathrm{~km}^{2}$. The stretch of the river system available to anadromous fish consists of the River Namsen (the main river) and the 2 main tributaries, Høylandsvassdraget and Sanddøla (Fig. 1). River Namsen has a mean annual water discharge at the river mouth of $290 \mathrm{~m}^{3} \mathrm{~s}^{-1}$. In the main river, anadromous salmonids could previously migrate $70 \mathrm{~km}$ upriver from the sea to the $35 \mathrm{~m}$ high waterfall Nedre Fiskumfoss. In 1977, a fish ladder was constructed in this waterfall, adding $10 \mathrm{~km}$ to the anadromous stretch of the main river, to Aunfoss. The River Namsen is a slow-flowing river, and there are no major migration barriers for Atlantic salmon below Nedre Fiskumfoss. In 2012, Atlantic salmon spawning redds were counted from a helicopter. Spawning redds were recorded in all parts of the River Namsen above the saltwater-influenced estuary. This distribution of spawning redds indicates that most parts of the river contain suitable spawning areas for Atlantic salmon (Fig. 1). The total length of accessible stretches for anadromous salmonids in the entire river system, including the tributaries, is $200 \mathrm{~km}$. Based on examination of the gonads of farmed and wild salmon caught in the river in 2012, most, if not all fish entering the River Namsen were sexually mature. 


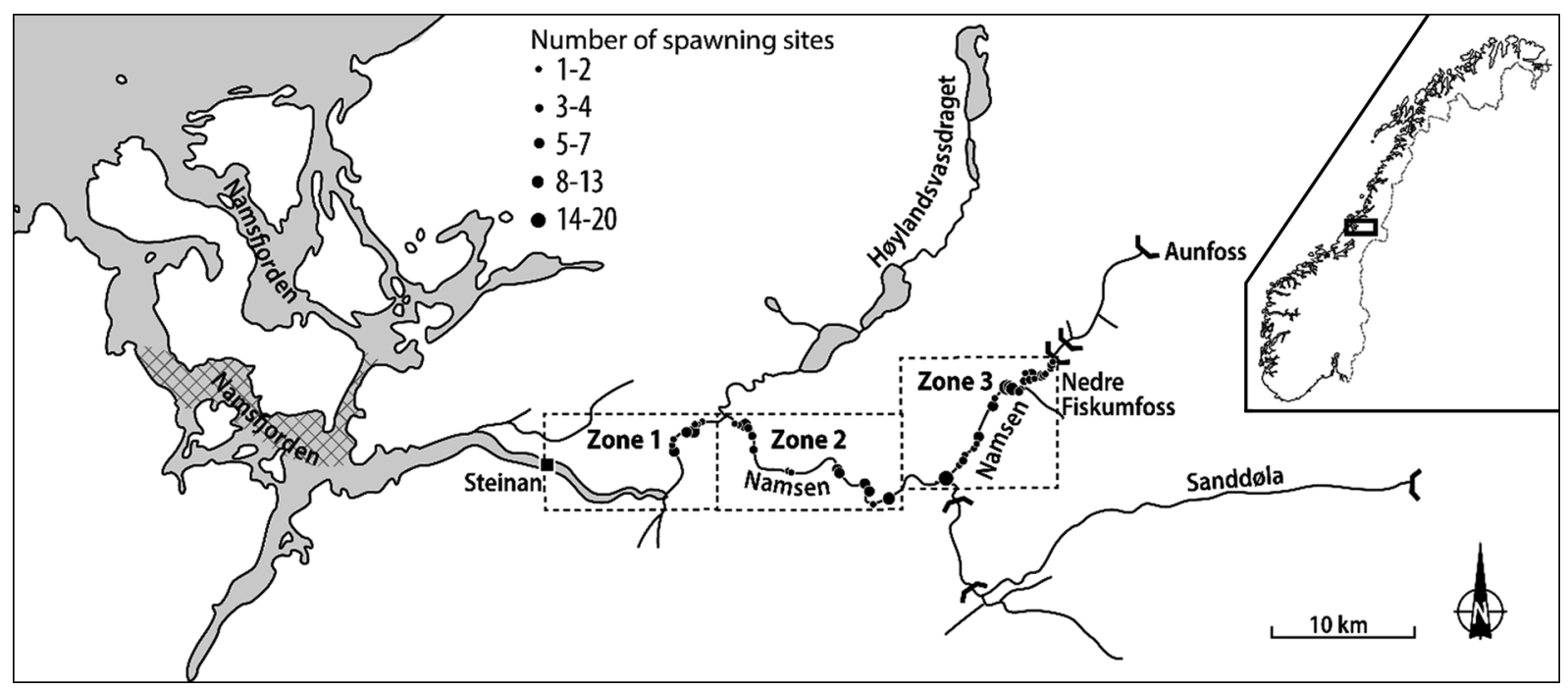

Fig. 1. Namsfjorden and the Namsen river system, showing locations of bag nets where Atlantic salmon Salmo salar were

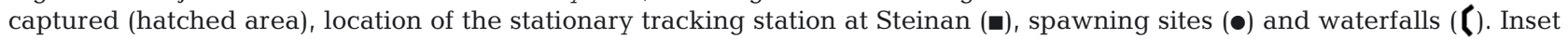
shows the location of the study site in Central Norway. River zones are outlined by rectangles with dotted lines. Graphics: Kari Sivertsen, NINA

\section{Fish capture and tagging}

A total of 74 wild (24 males, 49 females, 1 unknown sex), and 43 escaped farmed Atlantic salmon (15 males, 15 females, 13 unknown sex) were captured in bag nets in the sea (Namsfjorden, 5.5 to $21.8 \mathrm{~km}$ from the river mouth) and tagged with radio transmitters between 10 June and 28 August 2012 (Fig. 1). Farmed Atlantic salmon entered the fjord later than wild Atlantic salmon, hence $29(67 \%)$ of the farmed fish were tagged between 31 July and 29 August, while 71 $(96 \%)$ of the wild salmon were tagged between 15 June and 27 July. Mean $( \pm \mathrm{SD})$ total body length was $88 \pm 9 \mathrm{~cm}$ (range: 67 to $109 \mathrm{~cm}$ ) for the wild and $78 \pm$ $8 \mathrm{~cm}$ (range: 64 to $93 \mathrm{~cm}$ ) for the farmed salmon (for further details, see Table S1 in Supplement 1 at www. int-res.com/articles/suppl/q008p077_supp.pdf).

Each fish was tagged with a radio transmitter (model F2120, Advanced Telemetry Systems; outline dimensions: $21 \times 52 \times 11 \mathrm{~mm}$, mass in air: $15 \mathrm{~g}$, guaranteed battery life: 149 to $269 \mathrm{~d}$ ) according to the method described by Thorstad et al. (1998) and Økland et al. (2001). The fish were anesthetized before tagging (2-phenoxyethanol, EEC No 204-589-7, $1 \mathrm{ml}$ $\mathrm{l}^{-1}$ of water). Similar transmitters did not reduce the swimming performance of similarly-sized Atlantic salmon in a swim speed chamber (Thorstad et al. 2000). Each individual fish was recognized based on a unique combination of pulse rate and frequency (within the 142.000 to $142.600 \mathrm{MHz}$ range). Identifi- cation of escaped farmed individuals was based on morphological characteristics and controlled with analysis of growth patterns in 5 to 8 scales collected from each fish during tagging (Fiske et al. 2005). Sex was determined based on external characteristics, if possible. The fish were released at the catch site after tagging and recovery from anesthetization.

\section{Tracking of tagged salmon}

The tagged fish were manually tracked from a car using a radio receiver (R4500S ATS) and a whip antennae mounted on the car roof $(142 \mathrm{MHz}$, Laird Technologies). Between 4 July and 15 November 2012, the entire river system accessible to Atlantic salmon was tracked every second week to determine the position of all radio-tagged fish that had entered the watercourse. The large size of the watershed and limited accessibility of certain parts made manual tracking of the entire system too time consuming; hence, the study focused on the main river, River Namsen. Of the 74 wild and 43 farmed Atlantic salmon tagged in the fjord, $59(78 \%)$ and $32(74 \%)$ entered the watercourse, respectively. Of these, 2 wild and 2 farmed salmon were registered on only one occasion, and 18 wild and 6 farmed salmon migrated into the tributaries River Høylandsvassdraget and River Sanddøla (Fig. 1). In addition, 1 farmed Atlantic salmon passed the fish ladder at 
Nedre Fiskumfoss (Fig. 1), and 20 wild and 5 farmed salmon were caught in the recreational fisheries in the main river. These individuals were therefore excluded from the study, leaving a sample size of 19 wild and 18 farmed Atlantic salmon.

The location of the tagged fish was determined every second day in the main river between Steinan (saltwater influence and no spawning areas downstream of this site) and the Nedre Fiskumfoss waterfall (a $57 \mathrm{~km}$ stretch of river; Fig. 1), using 75 permanent tracking stations. The distance between tracking stations was on average $800 \mathrm{~m}$ (range: 167 to $1673 \mathrm{~m}$ ). Tagged fish were assigned to the tracking station at which the strongest signal was received. The detection range of the receiver varied between stations (between approximately 0.5 and $2.0 \mathrm{~km}$ ). Hence, in a few areas the detection range may have been shorter than the distance between tracking stations due to topography and vegetation.

Tagged fish were tracked every second day during the pre-spawning (4 September to 4 October 2012) and spawning period (5 October to 10 November 2012) of wild Atlantic salmon. Timing of the spawning period was based on a previous study (Thorstad et al. 1998), and confirmed by personal communication with local fishers.

To investigate how the tagged fish used different areas of River Namsen, the river was divided into 3 equally sized zones (19 to $20 \mathrm{~km}$ long) from Steinan to Nedre Fiskumfoss (Fig. 1). Movement distances were calculated using the 'locate features along routes' and 'make route event layer' tools in ArcGIS. This was done by using a centreline of the river to calculate the distance from the river mouth to each tracking position.

\section{Statistical analyses}

Our analyses were based on the tagged Atlantic salmon that were recorded in the River Namsen during the pre-spawning and spawning periods (excluding those recaptured by anglers after entering the river). In the pre-spawning period, 18 farmed and 19 wild salmon were included in the analysis of area use, total migration distance and daily movements. The analysis of daily downstream migration distances were based on 17 farmed and 18 wild salmon in the pre-spawning period, because 2 individuals (1 farmed and 1 wild salmon) did not exhibit any downstream movements. Details on sample sizes in the different analyses are provided in Table S2 of Supplement 1. During the spawning period, 17 farmed and 17 wild Atlantic salmon were included in the analysis on area use, total migration distances and daily movements. One farmed salmon was recaptured on 6 October, and was therefore included in the pre-spawning, but not the spawning period analyses. Two wild salmon moved out of the main river after the pre-spawning period, and were consequently removed from the spawning period analysis. The calculations of daily downstream migration distances were conducted on 15 farmed and 16 wild Atlantic salmon in the spawning period, due to 3 individuals ( 2 farmed and 1 wild) that did not exhibit any downstream movements (details on sample sizes in the different analyses are given in Table S2 of Supplement 1). One farmed Atlantic salmon passed the fish ladder in Nedre Fiskumfoss and migrated further upstream. This individual was not regularly tracked because of a restricted capacity to extend the tracking area required to cover its movements, and was therefore excluded from the analyses. If the most supported model included sex as a factor, individuals with unknown sex were removed from the analysis.

Data on area use and the probability of migrating to the barrier was analyzed using generalized linear mixed effect models (GLMM) (Pinheiro \& Bates 2000, Zuur et al. 2009). The probability of migrating to the Nedre Fiskumfoss waterfall barrier was modelled by fitting a generalized linear model (GLM) with logit link function fitted to the binomial response ' 1 ' for those fish that reached the barrier, and ' 0 ' for those that did not. The GLMMs were fitted using the 'lme4' package in $\mathrm{R}$ (Bates et al. 2014). In order to account for within-individual dependency of the observations, the individual fish identification (ID) was a priori included as random factor. ANCOVAs including origin, sex and length as explanatory variables were used to test for differences in total daily movement distance, daily downstream movement distance and number of daily movements (i.e. the number of observations where the fish was located in a different tracking station from one tracking event to the next, divided by the number of days in the observation period).

In order to estimate how the salmon's origin, body length and sex and day of year affected the probability of remaining in a certain river section during given time periods, we fitted multinomial logit models to individual-specific mean positions data for both pre-spawning and spawning periods (Hosmer \& Lemeshow 1989). All 2-way interactions were included in the global model. The mean position was assigned to 1 of 3 equally sized river zones (Fig. 1). The models were fitted using the 'multinom' function 
of the 'nnet' package in R. Effect tests for the multinomial modes were performed using type III likelihood ratio (LR) tests running the ANOVA procedure available from the R package 'car'.

Model selection for fixed effects followed the combined Akaike information criterion (AICc) and backward-selection procedures available in Zuur et al. (2009). For the random structure, ID was a priori included in the models and thus not subjected to model selection (see Supplement 2 at www.intres.com/articles/suppl/q008p077_supp.pdf for further details on model selection).

\section{RESULTS}

\section{Area use in the pre-spawning period}

The distribution of wild and escaped farmed Atlantic salmon differed throughout the pre-spawning period (Fig. 2). A total of 9 farmed $(50 \%)$ and 2 wild $(11 \%)$ fish migrated to the barrier at the Nedre Fiskumfoss waterfall. The most supported GLM to predict the probability of migrating to the barrier included only origin (see Table S6 in Supplement 2). The predicted probability of farmed Atlantic salmon migrating to the barrier was 0.5 (95\% CI: 0.28-0.72), while that of wild Atlantic salmon was $0.1(95 \% \mathrm{CI}$ : $0.03-0.34)\left(\operatorname{LR} \chi^{2}=37.7, \mathrm{df}=35, \mathrm{p}<0.01\right)$.

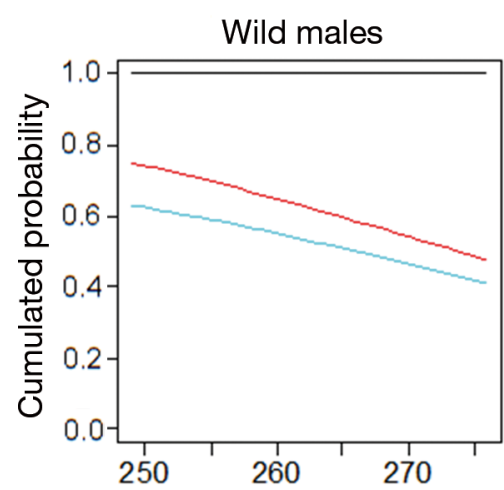

Farmed males

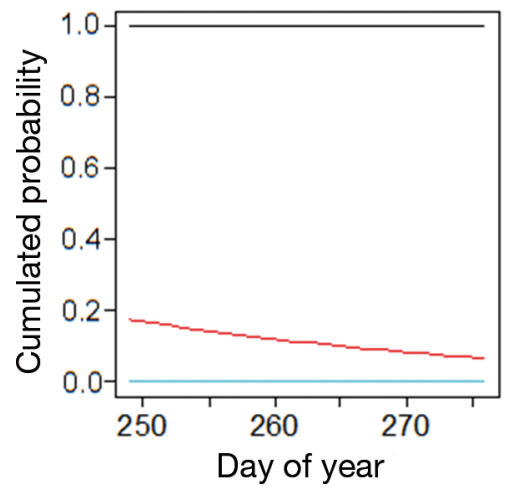

Wild females

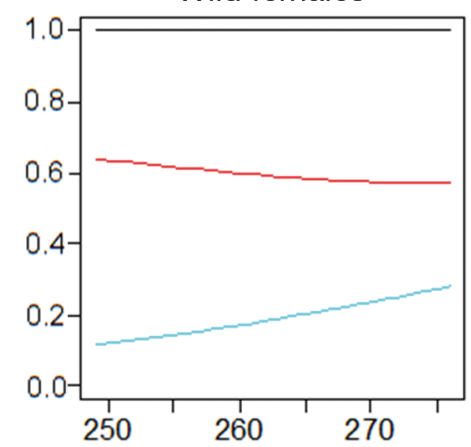

Farmed females

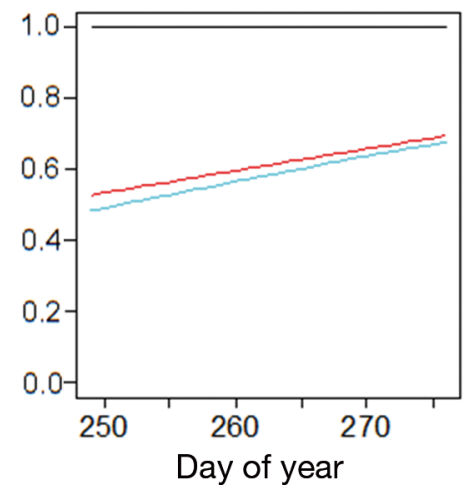

Fig. 3. Predicted probability of use of river stretches (zones) by Atlantic salmon Salmo salar in the pre-spawning period as a function of origin, sex and day of year. $\mathrm{N}=11$ wild females, 8 wild males, 5 farmed females, and 7 farmed males. Individuals of unknown sex were excluded

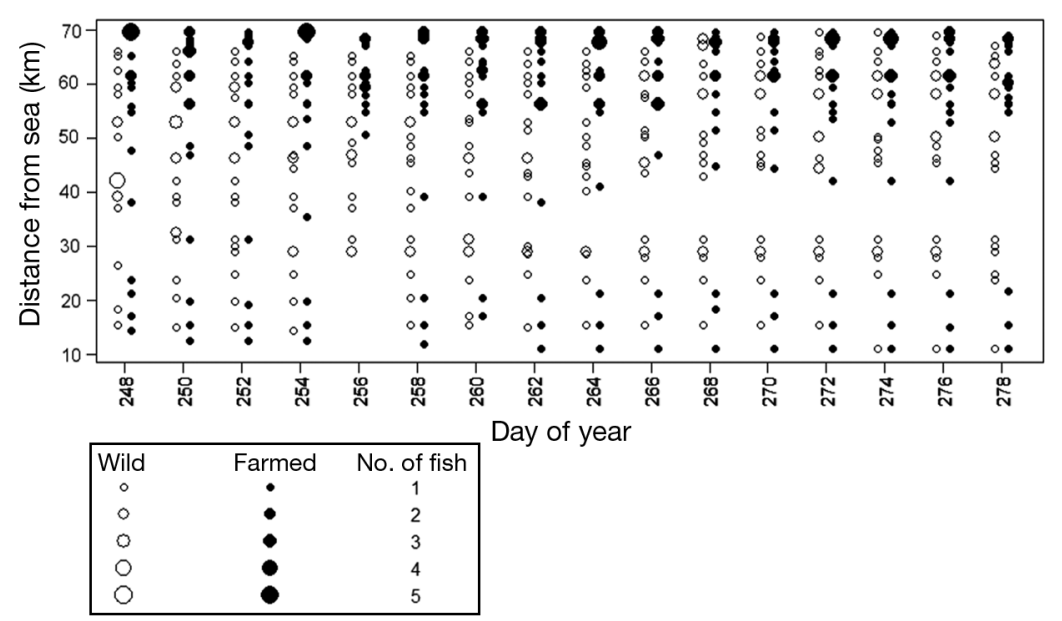

Fig. 2. Location (distance from the river mouth) of farmed and wild Atlantic salmon Salmo salar on day of the year 248 to 278 (4 September to 4 October 2012). On Day 256 (12 September), the lower $28 \mathrm{~km}$ were not manually tracked. For clarity in the figure, minor temporal separation of wild and farmed salmon observations have been made
Fourteen of the 18 (78\%) farmed Atlantic salmon moved to, and stayed within the upper $30 \mathrm{~km}$ of the $70 \mathrm{~km}$ river stretch, while 3 individuals remained in the lower $20 \mathrm{~km}$ (Fig. 2). In contrast, the wild Atlantic salmon were distributed evenly over the entire river stretch.

Males and females had different probabilities of using the 3 river zones (lower, middle and upper) during the pre-spawning period (Fig. 3). The most supported multinomial zone-use model included the predictors origin, sex and day of year, and all 2-way interactions. There was a significant interaction between origin and sex (multinomial GLM: $\mathrm{LR} \chi^{2}=128.4, \mathrm{df}=2, \mathrm{p}<0.001$; Fig. 3). None of the other factors or their interactions were significant (all $p>0.09$ ). Farmed males had a higher predicted probability of using the up- 
per section (50 to $70 \mathrm{~km}$ ) than both sexes of wild Atlantic salmon (Fig. 3). Farmed females used the lower (10 to $30 \mathrm{~km}$ ) and upper (50 to $70 \mathrm{~km}$ ) sections but not the middle section. In contrast, wild females used all river sections while wild males had a similar pattern to farmed females, mainly using the lower and upper sections during the prespawning period (Fig. 3).

\section{Area use in the spawning period}

The distribution of wild and farmed Atlantic salmon differed throughout the spawning period (Fig. 4). All but 3 farmed salmon remained in the upper $20 \mathrm{~km}$ during the spawning period; no farmed salmon were found in the middle $30 \mathrm{~km}$. In contrast, wild salmon were distributed evenly over the whole river (Fig. 4).

Males and females had different probabilities of using the 3 river zones (lower, middle and upper) during the spawning period (Fig. 5). The river section used was best explained by the multinomial GLM model, including the predictors origin, sex and day of year, without including the 3-way interaction between these predictors (origin $\times$ sex: $\mathrm{LR} \chi^{2}=59.4, \mathrm{df}=2, \mathrm{p}<<0.001$; day of year $\times$ origin: $\mathrm{LR} \chi^{2}=17.0, \mathrm{df}=2, \mathrm{p}<0.001$; day of year $\times$ sex: $\operatorname{LR} \chi^{2}=14.4, \mathrm{df}=2, \mathrm{p}<0.001$; effect of origin: $\mathrm{LR} \chi^{2}=13.6, \mathrm{df}=2, \mathrm{p}=0.001$;
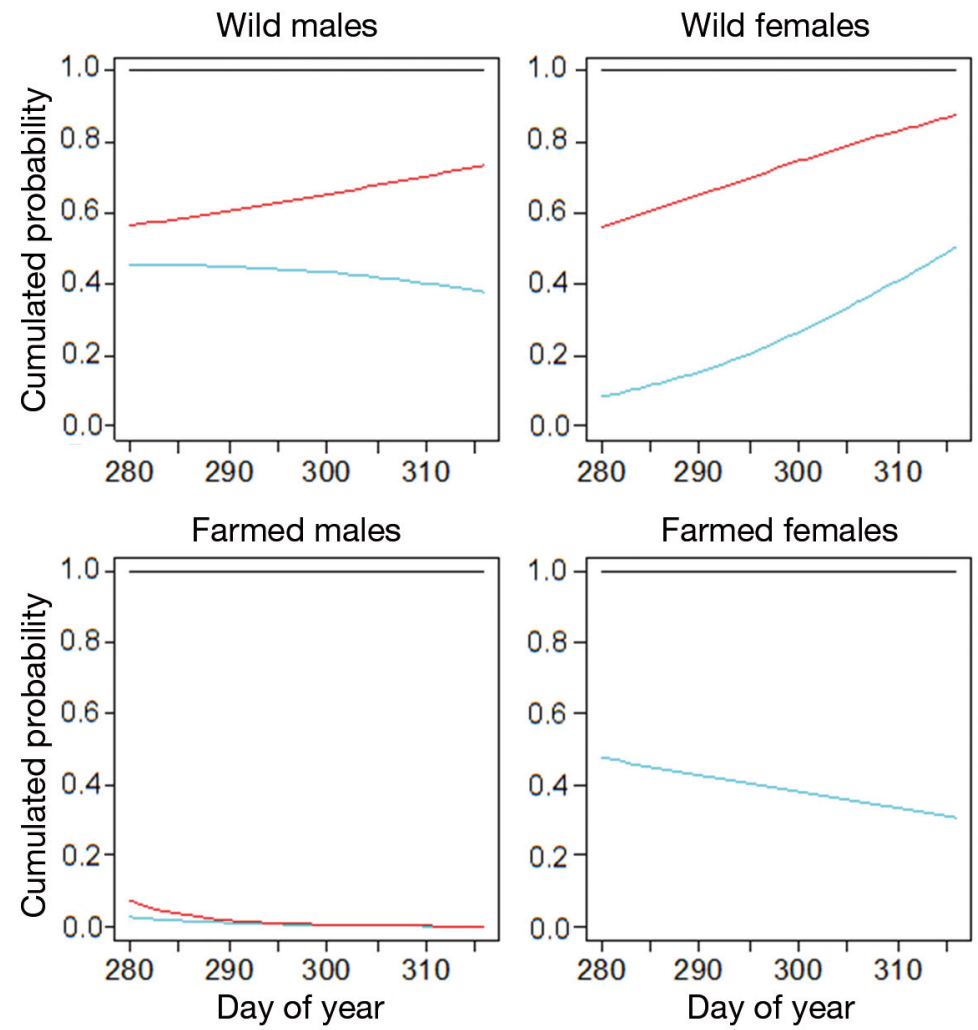

Fig. 5. Predicted probability of use of river stretches (zones) by Atlantic salmon Salmo salar during the spawning period as function of origin, sex and day of year. $\mathrm{N}=11$ wild females, 8 wild males, 5 farmed females, and 7 farmed males. Individuals of unknown sex were excluded

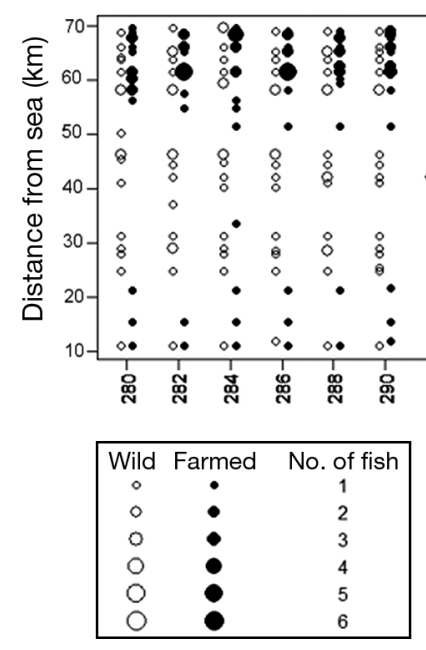

Fig. 4. Location (distance from the river mouth) of farmed and wild Atlantic salmon Salmo salar on day of the year 280 to 314 (6 October to 10 November 2012). For figure clarity, minor temporal separation of wild and farmed salmon observations have been made effect of sex: LR $\chi^{2}=5.1, \mathrm{df}=2, \mathrm{p}=0.078$; effect of day of year: $L R \chi^{2}=3.1, \mathrm{df}=2, \mathrm{p}=$ 0.211). Farmed males had a higher predicted probability of using the upper section (50 to $70 \mathrm{~km}$ from the river mouth) than both sexes of wild salmon (Fig. 5). None of the radio-tagged farmed females used the middle section (30 to $50 \mathrm{~km}$ ) during the spawning period; they were found either in the lower $(10$ to $30 \mathrm{~km})$ or upper section (50 to $70 \mathrm{~km}$ ). Wild females used all sections, but the probability of using the middle and lower sections increased with the day of year, indicating that some individuals moved downstream after spawning. The probability of wild males using the middle section increased with the day of year, while the probability of using the lower section decreased (Fig. 5). 


\section{Movement patterns in the pre-spawning period}

Farmed Atlantic salmon performed longer movement distances per day than wild salmon (Table 1). Wild salmon $(\mathrm{n}=19)$ moved on average $( \pm \mathrm{SD}) 528 \pm 459 \mathrm{~m} \mathrm{~d}^{-1}$ (median: 436, range: 118 to $1785 \mathrm{~m} \mathrm{~d}^{-1}$ ), while farmed individuals $(\mathrm{n}=18)$ moved on average $871 \pm 510 \mathrm{~m} \mathrm{~d}^{-1}$ (median: 730, range: 293 to $2295 \mathrm{~m} \mathrm{~d}^{-1}$ ) based on cumulative movements. Body length affected movement distance differently in wild and farmed salmon (ANCOVA: $\mathrm{R}^{2}=0.26, F=3.79, \mathrm{p}=$ $0.02)$. The movement distance per day increased with body length in farmed individuals, while it decreased with body length in wild individuals. There was no difference in total movement distance per day between males and females (Table 1, Fig. 6). Two farmed Atlantic salmon had a large effect on the linear model parameter estimates, but the results were significant even when these individuals were excluded from the analyses.

The average downstream movements for wild ( $\mathrm{n}=$ 18) and farmed salmon $(\mathrm{n}=17)$ were $304 \pm 232 \mathrm{~m} \mathrm{~d}^{-1}$ (median: 286, range: 74 to $782 \mathrm{~m} \mathrm{~d}^{-1}$ ) and $448 \pm 305 \mathrm{~m}$ $\mathrm{d}^{-1}$ (median: 367, range: 11 to $1177 \mathrm{~m} \mathrm{~d}^{-1}$ ), respectively. Body length affected downstream movement distance differently in wild and farmed fish
Table 1. Parameter estimates for the most supported linear models to predict total daily movement distance, downstream movement distance and number of daily movements of wild and escaped farmed Atlantic salmon Salmo salar during the pre-spawning period. All estimates are reported as contrasts

\begin{tabular}{|c|c|c|c|c|}
\hline Model & $\begin{array}{l}\text { Explanatory } \\
\text { variable }\end{array}$ & $\begin{array}{c}\text { Estimate } \\
( \pm \mathrm{SE})\end{array}$ & $t$ & $\mathrm{p}$ \\
\hline Total distance $\mathrm{d}^{-1}$ & Intercept [Farmed] & $-1187(1074)$ & -1.11 & 0.28 \\
\hline \multirow[t]{3}{*}{$\sim$ Origin $\times$ Length } & Origin [Wild] & 3635 (1600) & 2.27 & 0.03 \\
\hline & Length & $26(13)$ & 1.93 & 0.06 \\
\hline & Origin [Wild] $\times$ Length & $-47(19)$ & -2.51 & 0.02 \\
\hline $\begin{array}{c}\text { Downstream } \\
\text { distance } d^{-1}\end{array}$ & $\begin{array}{l}\text { Intercept } \\
\text { [Farmed] }\end{array}$ & $-1467(620)$ & -2.37 & 0.024 \\
\hline \multirow[t]{3}{*}{$\sim$ Origin $\times$ Length } & Origin [Wild] & $1998(887)$ & 2.25 & 0.032 \\
\hline & Length & $24(8)$ & 3.10 & 0.004 \\
\hline & Origin [Wild] $\times$ Length & $-26(10)$ & -2.52 & 0.017 \\
\hline Movements $\mathrm{d}^{-1}$ & Intercept [Farmed, Female] & $0.48(0.05)$ & 10.20 & $<0.001$ \\
\hline \multirow[t]{3}{*}{$\sim$ Origin + Sex } & Origin [Wild] & $-0.19(0.06)$ & -3.39 & 0.002 \\
\hline & Sex [Male] & $-0.20(0.06)$ & -3.31 & 0.003 \\
\hline & Origin [Wild] $\times$ Sex & $0.14(0.08)$ & 1.74 & 0.094 \\
\hline
\end{tabular}

(ANCOVA: $\mathrm{R}^{2}=0.29, F=4.3, \mathrm{p}=0.01$ ). Daily downstream movement increased with body length in farmed individuals, while body length had no effect on downstream movement distance in wild individuals. There was no difference in downstream movement distance per day between males and females (Table 1, Fig. 7). There were no significant differences between wild and farmed Atlantic salmon in the average number of downstream movements, since origin alone did not have a significant effect on
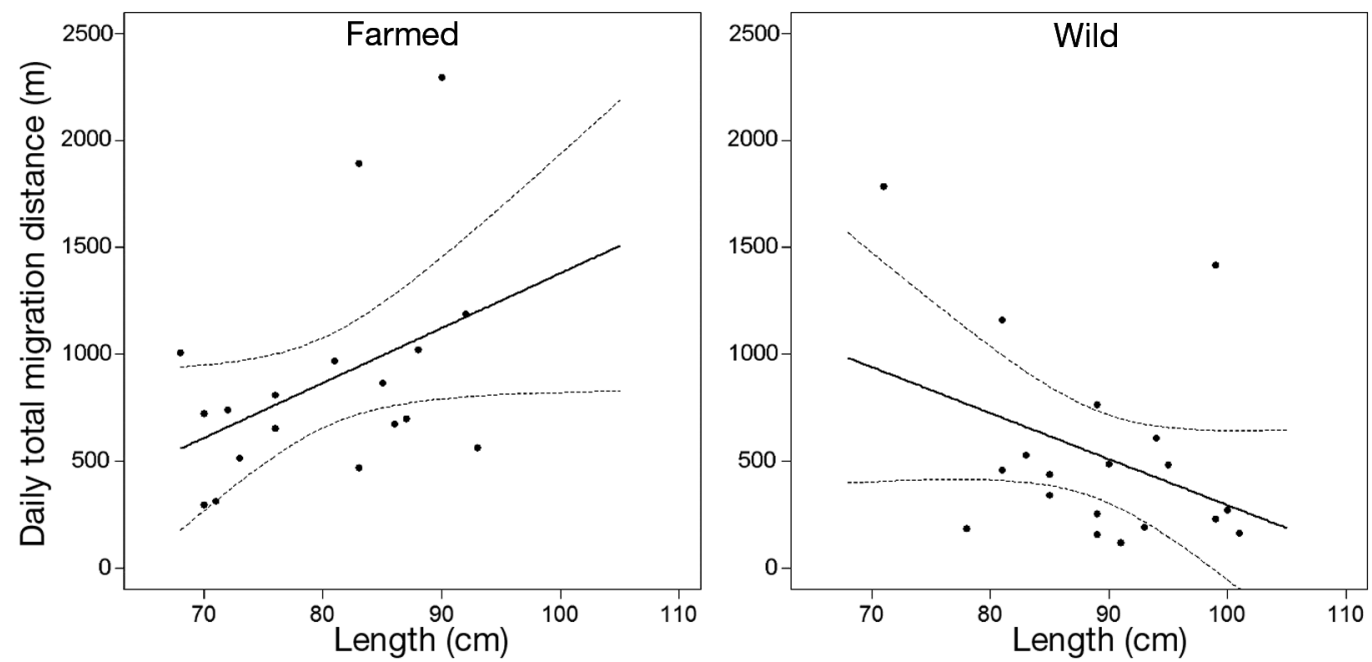

Fig. 6. Predicted (solid line) daily total movement distance of Atlantic salmon Salmo salar plotted as a function of body length and origin, showing upper and lower $95 \%$ CI (dotted lines). Dots: observed values. The predictions were retrieved from the linear model provided in Table 1. $\mathrm{N}=19$ wild and 18 farmed Atlantic salmon 

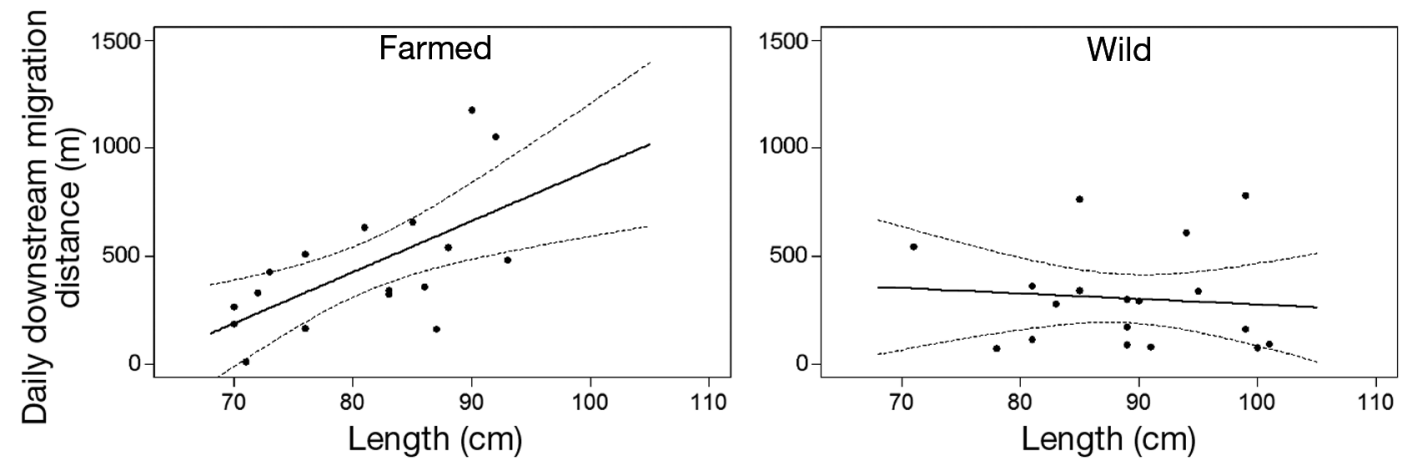

Fig. 7. Predicted (solid line) daily downstream movement distance of Atlantic salmon Salmo salar plotted as a function of body length and origin, showing upper and lower 95\% CI (dotted lines). Dots: observed values. The predictions were retrieved from the linear model provided in Table 1. $\mathrm{N}=18$ wild and 17 farmed Atlantic salmon

downstream movements (ANOVA: $\mathrm{R}^{2}=0.07, F=2.5$, $\mathrm{p}=0.12)$.

Wild Atlantic salmon moved on average $0.26 \pm 0.12$ times $\mathrm{d}^{-1}$ (median: 0.23 , range: 0.07 to 0.53 times $\mathrm{d}^{-1}$ ) while farmed salmon moved on average $0.36 \pm 0.13$ times $\mathrm{d}^{-1}$ (median: 0.35 , range: 0.13 to 0.63 times $\mathrm{d}^{-1}$ ). Sex had the same effect on number of daily move-

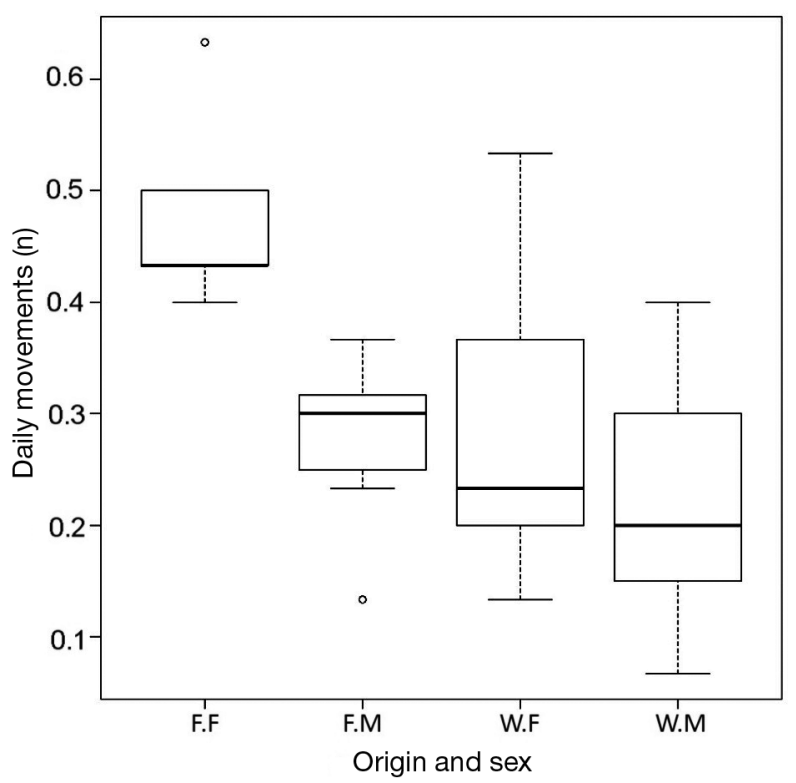

Fig. 8. Observed number of daily movements of Atlantic salmon Salmo salar as a function of origin and sex. The bottom and top of the box delineate the $25^{\text {th }}$ and $75^{\text {th }}$ percentiles (i.e. the boxes include the middle $50 \%$ of the observations). The whiskers span to the most extreme data point, which is no more than 1.5 times the interquartile rage, and the bold horizontal line represents the median value. W.F: wild females $(\mathrm{n}=11)$; W.F: wild males $(\mathrm{n}=8)$; F.F: farmed females $(n=5) ;$ F.M: farmed males $(n=7)$. Individuals of unknown sex were excluded ments in both wild and farmed individuals (ANOVA: $\mathrm{R}^{2}=0.42, F=6.6, \mathrm{p}=0.002$ ). Females exhibited more daily movements than males in both groups, but less so among the wild than the farmed salmon (as indicated by a trend towards an interaction between sex and origin; see Table 1). Farmed individuals exhibited more daily movements than wild fish for both sexes (Table 1, Fig. 8).

\section{Movement patterns in the spawning period}

Wild and farmed Atlantic salmon did not differ in behavior during the spawning period. Farmed salmon moved a mean distance of $435 \pm 622 \mathrm{~m} \mathrm{~d}^{-1}$ (median: 252, range: 27 to $2680 \mathrm{~m} \mathrm{~d}^{-1}$ ), while wild Atlantic salmon moved a mean distance of $492 \pm 357$ $\mathrm{m} \mathrm{d}^{-1}$ (median: 369, range: 68 to $1273 \mathrm{~m} \mathrm{~d}^{-1}$ ). Daily movement distance was not affected by origin, sex or body length (ANCOVA: all $\mathrm{p} \geq 0.1$ ).

Three individuals ( 2 farmed, 1 wild) did not register any downstream movements during the spawning period. Of the fish that did move, farmed fish $(\mathrm{n}=$ 15) moved a mean downstream distance of $289 \pm 363$ $\mathrm{m} \mathrm{d}^{-1}$ (median: 196, range: 27 to $1499 \mathrm{~m} \mathrm{~d}^{-1}$ ), while wild salmon $(\mathrm{n}=16)$ moved a mean downstream distance of $387 \pm 300 \mathrm{~m} \mathrm{~d}^{-1}$ (median: 312, range: 41 to $1053 \mathrm{~m} \mathrm{~d}^{-1}$ ). Downstream movement distance was not dependent on origin, sex or body length (ANCOVA: all $\mathrm{p} \geq 0.15$ ).

Farmed salmon moved on average $0.2 \pm 0.1$ times $\mathrm{d}^{-1}$ (median: 0.2 , range: 0.3 to 0.5 times $\mathrm{d}^{-1}$ ), while wild individuals moved an average of $0.2 \pm 0.2$ times $\mathrm{d}^{-1}$ (median: 0.2 , range: 0 to 0.7 times $\mathrm{d}^{-1}$ ). The number of movements was not dependent on origin, sex or body length (ANCOVA: all $\mathrm{p} \geq 0.3$ ). 


\section{DISCUSSION}

\section{Area use in the pre-spawning period}

In the pre-spawning period, escaped farmed Atlantic salmon mainly stayed in the upper part of the river, while wild salmon were evenly distributed from the river mouth to the upper river section. The predicted probability of migrating to the migration barrier $70 \mathrm{~km}$ upstream from the river mouth was 4 times higher for farmed than for wild salmon. These findings support results of earlier studies of upstream migration in escaped farmed Atlantic salmon (Butler et al. 2005, Heggberget et al. 1996, Thorstad et al. 1998), which indicate that farmed salmon, as opposed to native wild individuals, do not have a 'stop signal' when migrating upstream, probably due to lack of imprinting to a certain home site in the river. Consequently, farmed individuals may aggregate below migration barriers in the upper parts of the rivers. Being immature or in poor physical condition may be potential reasons that a few farmed individuals did not migrate this far.

Differences in distribution of wild and escaped farmed Atlantic salmon should be taken into consideration when estimating the proportion of farmed salmon in rivers during the pre-spawning period. The proportion of escaped individuals in rivers is typically monitored by collecting scale samples from angling catches during the regular fishing season, and targeted angling or net fishing in different areas in the pre-spawning period, often close to the spawning period after the regular angling season has ended (Fiske et al. 2005). The proportions of escaped farmed salmon are determined based on morphology and scale analyses of the captured fish (Fiske et al. 2005). Those individuals that are identified as wild based on morphology are released back into the river alive after a scale sample is collected for later verification of wild versus farmed origin. Fish that are identified as escaped farmed salmon based on morphology are killed. Monitoring of escaped farmed salmon is also based on visual identification of wild and farmed fish during drift snorkeling observations in clear-water rivers (Vollset et al. 2014), monitoring of fish ladders by video recordings, and in some instances capturing fish in the spawning areas by paralyzing them with strong light, taking scale samples and releasing them again (Anonymous 2015a). Our results indicate that the proportion of farmed Atlantic salmon captured or observed during such monitoring activities would be sensitive to both timing and location of sampling. Hence, a non-biased sampling programme for assessing the proportion of escaped farmed Atlantic salmon in the River Namsen and other similar rivers should be accomplished after most of the escaped individuals have entered the river, and include samples from all river stretches equally, covering the lower, middle, and uppermost spawning areas.

\section{Area use in the spawning period}

During the spawning period, all except 3 farmed Atlantic salmon remained in the upper $20 \mathrm{~km}$ of the river below the migration barrier. In contrast, wild Atlantic salmon were distributed evenly from the lower river sections to the migration barrier. Farmed Atlantic salmon being distributed higher up the river than wild fish is in accordance with results from previous studies in the River Namsen and River Alta (Heggberget et al. 1996, Thorstad et al. 1998). However, both wild and farmed salmon stayed together in the upper reaches of the river, which hold important spawning grounds for wild Atlantic salmon. It is likely that spawning between wild and escaped farmed salmon takes place in these areas. Hybridization between farmed and wild Atlantic salmon in the River Namsen has recently been documented by genetic methods (S. Karlsson et al. unpubl. data). From our findings of spatial variation in the degree of overlapping area use between wild and farmed individuals, a varying degree of hybridization can be expected.

\section{Movement patterns in the pre-spawning period}

The escaped farmed salmon exhibited longer total movement distances and more movements per day than did wild individuals during the pre-spawning period. However, when downstream movements were analyzed separately, there was no significant difference between the 2 groups. This may be because a proportion of farmed Atlantic salmon had not completed their upstream migration in the river when the study began, while the wild salmon had entered the river earlier and may have finished their searching phase and started their holding phase close to their spawning area (Økland et al. 2001, Finstad et al. 2005).

The daily total and downstream movement distances of the tagged individuals indicated that movement distances increased with body length for farmed salmon, while body length had little or no 
effect on the wild individuals' movements. To the best of our knowledge, no previous studies have found that movement distances of farmed Atlantic salmon are related to body length. These within-river movements were short compared to total migration distances and likely not related to restricted energy reserves in the smaller fish, but rather to some other intrinsic factors affecting their behavior.

Females exhibited more daily movements than males in both wild and farmed salmon. The reason may be that females actively searched for a suitable spawning site at different localities prior to spawning (Fleming 1996). Similar to our study, Karppinen et al. (2004) found that wild females tended to exhibit a more erratic migration pattern than wild males, while Økland et al. (2001) and Finstad et al. (2005) did not find differences in movement patterns between wild males and females.

\section{Movement patterns in the spawning period}

During the spawning period, there were no differences in daily total and downstream movement distances between wild and escaped farmed Atlantic salmon, or in the number of daily movements. This is in contrast to earlier studies, which documented more extensive up- and downstream movements in farmed than in wild salmon during the spawning period (Thorstad et al. 1998, Økland et al. 1995). Both in the present and previous studies, there were substantial among-individual variations within both groups. A possible reason for this lack of difference may be that the accuracy of the manual tracking used in our study was too low to detect possible smallscale movements. For instance, movements between spawning grounds located $200 \mathrm{~m}$ apart in the same area of the river would not have been documented. Furthermore, the individuals may have moved and returned between manual tracking days. Hence, the estimated movement distances and the number of daily movements reported here are most likely underestimated. Another factor that may have affected our results is that not all tagged individuals were located during every manual-tracking day. However, most of the fish had a high number of detections in the pre-spawning (14 to 16 out of 16 tracking days) and spawning (17 to 19 of 19 tracking days) periods.

Farmed Atlantic salmon are subject to selection regimes geared toward optimizing their life history characteristics (such as growth and size at sexual maturation), which now may differ considerably from populations of wild Atlantic salmon and from earlier generations of farmed salmon (Thodesen et al. 1999, Gjedrem \& Baranski 2009). Hence, in our study we also aimed to investigate if $19 \mathrm{yr}$ of both intentional and unintentional selection had changed the behavior of the farmed salmon. Based on Thorstad et al. (1998) and the present study, the general area of use of escaped farmed Atlantic salmon in the River Namsen was still the same during the spawning period, since the farmed salmon were mainly in the upper part of the river in both studies. However, selection may have changed the behavior of the escaped farmed Atlantic salmon, as their movements during the spawning period in the present study were more similar to the wild Atlantic salmon than 19 yr ago.

\section{CONCLUSIONS}

Results from this and previous studies (Butler et al. 2005, Heggberget et al. 1996, Thorstad et al. 1998) indicate that escaped farmed Atlantic salmon tend to migrate far upstream in the rivers until they reach major migration barriers, which results in a larger proportion of farmed individuals in upper compared to lower parts of rivers. Before the spawning period, these escaped individuals migrated back downstream from the migration barrier pool to nearby downstream spawning areas.

The within-river difference in distribution of farmed versus wild salmon, along with differences in the timing of pre-spawning and spawning, have implications for monitoring the incidence of escaped farmed Atlantic salmon in rivers. Monitoring of farmed and wild salmon should cover river sections in a standardized way to provide a representative sample from the river system.

In many Norwegian rivers, targeted angling or other capture methods are used to reduce the number of escaped farmed Atlantic salmon before spawning. The results of this and previous studies indicate that fishing in the upper parts of the rivers may be most effective in reducing the impact of escaped individuals. Results of the present study also indicate that hybridization between wild and escaped salmon is more likely to occur in the upper rather than the lower parts of the rivers due to the higher incidence of escaped farmed salmon in these areas.

The conclusion that escaped farmed Atlantic salmon tend to migrate far up in the rivers may not be valid for rivers with migration obstacles in lower parts. There are indications that farmed salmon are less capable than wild individuals of passing large 
and difficult waterfalls (Johnsen et al. 1998). Hence, in river systems with major migration barriers in lower river stretches, there may be an accumulation of escaped farmed salmon below the barriers. However, the ability of escaped individuals to pass large waterfalls has not been well studied.

Acknowledgements. We thank O. Diserud for comments on the statistical analysis, G. Østborg for scale analyses and S. Elden, L. Skorstad, J. A. Lanstad, R. Holm and F. Staldvik for technical assistance. Financial support was provided by the Norwegian Seafood Federation, the Directorate of Fisheries, the County Administrator at the Nord-Trøndelag County, and the County Authority of Nord-Trøndelag.

\section{LITERATURE CITED}

Anonymous (2015a) Rømt oppdrettslaks i vassdrag. Rapport fra det nasjonale overvåkningsprogrammet i 2014. Fisken og havet, særn. 2b-2015 (Report from the National Monitoring program in 2014)

Anonymous (2015b) Status for norske laksebestander i 2015 (Status of Norwegian salmon populations in 2015). Rapport fra Vitenskapelig råd for lakseforvaltning, NR8 (Report from the Norwegian Scientific Advisory Committee for Atlantic Salmon Management, in Norwegian)

Bates D, Maechler M, Bolker B, Walker S (2014) lme4: linear mixed-effects models using 'Eigen' and S4. R package version 1.1-7. http://CRAN.R-project.org/package=lme4

Butler JRA, Cunningham PD, Starr K (2005) The prevalence of escaped farmed salmon, Salmo salar L., in the River Ewe, western Scotland, with notes on their ages, weights and spawning distribution. Fish Manag Ecol 12:149-159

Ferguson A, Fleming IA, Hindar K, Skaala Ø, McGinnity P, Cross T, Prodohl P (2007) Farm escapes. In: Verspoor E, Strameyer L, Nielsen JL (eds) The Atlantic salmon: genetics, conservation and management. Blackwell Publishing, Oxford, p 357-398

Finstad AG, Økland F, Thorstad EB, Heggberget TG (2005) Comparing upriver spawning migration of Atlantic salmon Salmo salar and sea trout Salmo trutta. J Fish Biol 67:919-930

Fiske P, Lund RA, Hansen LP (2005) Identifying fish farm escapees. In: Cadrin SX, Friedland KD, Waldman JD (eds) Stock identification methods. Elsevier Academic Press, Amsterdam, p 659-680

Fleming IA (1996) Reproductive strategies of Atlantic salmon: ecology and evolution. Rev Fish Biol Fish 6: $379-416$

> Fleming IA, Hindar K, Mjolnerod IB, Jonsson B, Balstad T, Lamberg A (2000) Lifetime success and interactions of farm salmon invading a native population. Proc R Soc B 267:1517-1523

Garcia de Leaniz C, Fleming IA, Einum S, Verspoor E and others (2007) A critical review of adaptive genetic variation in Atlantic salmon: implications for conservation. Biol Rev Camb Philos Soc 82:173-211

Gjedrem T, Baranski M (eds) (2009) Selective breeding in aquaculture: an introduction. Springer, London

Glover KA, Quintela M, Wennevik V, Besnier F, Sørvik AGE, Skaala $\varnothing$ (2012) Three decades of farmed escapees in the wild: a spatio-temporal analysis of Atlantic salmon population genetic structure throughout Norway. PLoS ONE 7:e43129

Glover KA, Pertoldi C, Besnier F, Wennevik V, Kent M, Skaala $\varnothing$ (2013) Atlantic salmon populations invaded by farmed escapees: quantifying genetic introgression with a Bayesian approach and SNPs. BMC Genet 14:74

Hansen LP, Jonsson B, Andersen R (1989) Salmon ranching experiments in the River Imsa: Is homing dependent on sequential imprinting of the smolts? In: Brannon E, Johsson B (eds) Migration and distribution of salmonids: proceedings of the international salmoid migration and distribution symposium. University of Washington, Seattle, p $19-29$

Harden Jones FR (1968) Fish migration. Edward Arnold Publishers, London

Heggberget TG, Økland F, Ugedal O (1996) Prespawning migratory behaviour of wild and farmed Atlantic salmon, Salmo salar L., in a north Norwegian river. Aquacult Res 27:313-322

Hosmer DW, Lemeshow S (1989) Applied logistic regression. Wiley Interscience, New York, NY

ICES (2014) Report of the working group on North Atlantic salmon (WGNAS). ICES CM 2014/ACOM:09, 19-28 March 2014, Copenhagen

Jensen Ø, Dempster T, Thorstad EB, Uglem I, Fredheim A (2010) Escapes of fish from Norwegian sea-cage aquaculture: causes, consequences, prevention. Aquacult Environ Interact 1:71-83

Johnsen BO, Jensen AJ, Økland F, Lamberg A, Thorstad EB (1998) The use of radiotelemetry for identifying migratory behaviour in wild and farmed Atlantic salmon ascending the Suldalslågen river in Southern Norway. In: Jungwirth M, Schmutz S, Weiss S (eds) Fish migration and fish bypasses. Fishing New Books, Oxford, p 55-68

Karlsson S, Moen T, Hindar K (2010) Contrasting patterns of gene diversity between microsatellites and mitochondrial SNPs in farm and wild Atlantic salmon. Conserv Genet 11:571-582

Karppinen P, Erkinaro J, Niemela E, Moen K, Økland F (2004) Return migration of one-sea-winter Atlantic salmon in the River Tana. J Fish Biol 64:1179-1192

McGinnity P, Prodohl P, Ferguson A, Hynes R and others (2003) Fitness reduction and potential extinction of wild populations of Atlantic salmon, Salmo salar, as a result of interactions with escaped farm salmon. Proc R Soc B 270: 2443-2450

Økland F, Heggberget TG, Jonsson B (1995) Migratory behaviour of wild and farmed Atlantic salmon (Salmo salar) during spawning. J Fish Biol 46:1-7

Økland F, Erkinaro J, Moen K, Niemela E, Fiske P, McKinley RS, Thorstad EB (2001) Return migration of Atlantic salmon in the River Tana: phases of migratory behaviour. J Fish Biol 59:862-874

Pinheiro JC, Bates DM (2000) Mixed-effects models in S and S-PLUS. Springer, New York, NY

> Skaala Ø, Taggart J, Gunnes K (2005) Genetic difference between 5 major domesticated strains of Atlantic salmon and wild salmon. J Fish Biol 67:118-128

Taranger GL, Karlsen Ø, Bannister RJ, Glover KA and others (2015) Risk assessment of the environmental impact of Norwegian Atlantic salmon farming. ICES J Mar Sci 72: 997-1021

Thodesen J, Grisdale-Helland B, Helland SJ, Gjerde B (1999) Feed intake, growth and feed utilization of offspring from wild and selected Atlantic salmon (Salmo 
salar). Aquaculture 180:237-246

Thorstad EB, Heggberget TG, Økland F (1998) Migratory behaviour of adult wild and escaped farmed Atlantic salmon, Salmo salar L., before, during and after spawning in a Norwegian river. Aquacult Res 29: $419-428$

Thorstad EB, Økland F, Finstad B (2000) Effects of telemetry transmitters on swimming performance of adult Atlantic salmon. J Fish Biol 57:531-535

Thorstad EB, Økland F, Aarestrup K, Heggberget TG (2008) Factors affecting the within-river spawning migration of Atlantic salmon, with emphasis on human impacts. Rev

Editorial responsibility: Ian Fleming,

St. John's, Newfoundland and Labrador, Canada
Fish Biol Fish 18:345-371

Thorstad EB, Todd CD, Uglem I, Bjørn PA and others (2015) Effects of salmon lice Lepeophtheirus salmonis on wild sea trout Salmo trutta-a literature review. Aquacult Environ Interact 7:91-113

Vollset KW, Skoglund H, Barlaup BT, Pulg U and others (2014) Can the river location within a fjord explain the density of Atlantic salmon and sea trout? Mar Biol Res 10: 268-278

Zuur AF, Ieno EN, Walker N, Saveliev AA, Smith GM (2009) Mixed effects models and extensions in ecology with R. Springer, New York, NY

Submitted: March 26, 2015; Accepted: December 16, 2015 Proofs received from author(s): January 26, 2016 